\title{
A Perceptive and Reflective State?
}

\author{
Dahl, Hanne Marlene
}

Published in:

European Journal of Women's Studies

Publication date:

2000

Document Version

Early version, also known as pre-print

Citation for published version (APA):

Dahl, H. M. (2000). A Perceptive and Reflective State? European Journal of Women's Studies, 7(4), 475-494.

\section{General rights}

Copyright and moral rights for the publications made accessible in the public portal are retained by the authors and/or other copyright owners and it is a condition of accessing publications that users recognise and abide by the legal requirements associated with these rights.

- Users may download and print one copy of any publication from the public portal for the purpose of private study or research.

- You may not further distribute the material or use it for any profit-making activity or commercial gain.

- You may freely distribute the URL identifying the publication in the public portal.

Take down policy

If you believe that this document breaches copyright please contact rucforsk@kb.dk providing details, and we will remove access to the work immediately and investigate your claim. 


\section{A PERCEPTIVE AND REFLECTIVE STATE?}

The exercise of care within the welfare state is increasingly often placed on the political agenda. In the Danish context, public care has been criticized for either being too emotional or for showing too little affection. The diagnostics in dispute reflect what could be called various normative ideals for care: the perceptive state or the non-paternalistic state?

Feminists have not yet discussed how paid, public care should be performed. I think it is time to raise the issue and describe a normative ideal for waged, public care. I argue for an ideal between the perceptive and non-paternalistic state which I will tentatively call the perceptive and reflective state,(1) and which increasingly might become relevant for welfare states other than the Scandinavian ones. It is an ideal which combines thinking and empathy.(2)

My perspective is a feminist, normative and analytical one. I am concerned with the way care is theorized and the ideals governing its exercise within state-provided care, whether professional or not.(3) In my theorizing, I have been inspired by the empirical work carried out by Scandinavian researchers and by my own experiences at the receiving end of caring relations in the state. The general argument is that feminist research on care can constructively be related to political theory and philosophy. Using contemporary feminist theories of care as a starting point I will describe this theorization as being characterized by a sociological bias which is especially problematic in an analysis of paid and state provided care. Relating this tradition to political theory and philosophy might spin off analytical attention to previously not investigated aspects of power and to dilemmas within state-provided care. Concerning these dilemmas, I will argue that care seen as a social phenomenon, generally, is ambivalent and that reproduction going public makes the dilemmas more difficult, as well as 
creating new dilemmas.

Thus, a need for a new normative ideal for care arises, a view which I argue consists of $\underline{a}$ new official and professional ideal combined with a new form of authority, namely compassionate authority. This new official and professional ideal, which I propose, is a revised form of what Turkish-American philosopher Seyla Benhabib has called an interactive universalism. This modified form protects both caregiver and the recipient of care from emotional overload and disrespect. My main aim is to theorize some of the hitherto neglected aspects of public, waged care.(4) In my ideal I also inspired by Norwegian philosophers Arne Johan Vetlesen and Kari Martinsen and American political theorist Kathleen B. Jones.

In the remainder of this article, I will first briefly describe contemporary feminist theorizing of care and its rather limited view of power. Then I present the three types of dilemmas: care for oneself contra care for others, love contra justice and love contra knowledge. I describe the dilemmas and introduce Benhabib's interactive universalism as a temporary solution to one of the inherent dilemmas of state provided care: love contra justice. However, her ethics cannot function properly unless it is modified with a theorization of emotions and another form of authority. Vetlesen, Martinsen and Jones are introduced in order to revise Benhabib's ethics and I return to another dilemma: love contra knowledge. I turn first to contemporary feminist theories of care.

\section{Theorizing Care}

What is care more precisely? Where does it take place? How are decisions concerning care made? How has care in its various dimensions developed historically? These are some of the 
questions dealt with by feminist theories. The most central and influential theoreticians are British sociologists Hilary Graham, Clare Ungerson and the British historian Janet Finch, as well as the Scandinavian sociologists Kari Wærness, Arnlaug Leira and Rosmari Eliasson (Graham, 1983, 1991; Ungerson, 1983, 1987, 1995, 1997; Finch, 1989; Wærness, 1982, 1987; Leira, 1994; Eliasson, 1992).

They have developed a sophisticated theorization, which has generated new concepts about this scientifically neglected area of social bonds, caring needs and their relation to the continued oppression of women. Consequently, care has become visible on the scientific agenda. I will describe care as a concept as an 'essentially contested concept', e.g. as concept which reflects various theoretical, methodological and political aims. I therefore agree with the British sociologist Carol Thomas and her de-constructive enterprise. Thomas argues that concepts of care are all partial representations of 'care' in society (1993). Consequently, she urges us to define the parameters of the type of care that we are focussing on according to seven dimensions. My focus is upon the public social domain, and upon the waged form of an economic relationship. This kind of caregiving work might take place in the home of the recipient or in a state run institution.

Although theorization in the beginning was split into a British and a Scandinavian theory developing from different societal contexts, the two traditions have converged to some extent (Dahl, 1997). However, important differences remain concerning the perspective applied. Whereas the British tradition still brings the carer into focus, the Scandinavian tradition attempts to apply a double perspective: the carer and the cared for. In this sense, I will also subscribe to a Scandinavian perspective, since women also happen to be at both the providing and receiving ends of state-provided care.

Theories of care have analytically distinguished care from service, but disagree whether 
'care' as a concept is an exclusive term only applicable to the meeting of needs within the private sphere or a more general term (Graham, 1983, 1993; Bubeck, 1995). In this discussion I agree with the German-British philosopher Diemut Bubeck that care can encompass the meeting of needs in both the private and the public spheres (1995, 221-229). Bubeck defines care in the following way:

Caring for is the meeting of the needs of one person by another person where face-to-face interaction between carer and the cared for is a crucial element of the overall activity and where the need is of such a nature that it cannot possibly be met by the person in need herself $(1995,129)$.

Care in my view is an activity that presupposes needs that a person cannot meet by him or herself where needs are conventionally defined as Wærness argues (1982). Concepts such as carework, spontaneous caring services, commodified care as well as caregiving and professional care have entered our vocabulary in attempts to distinguish between various forms of care (Wærness, 1982; Davies, 1995; Ungerson, 1997). Leira and Eliasson have described care as a triad containing cognitive, emotional and practical elements, and claimed that good care should contain a synthesis of them (Eliasson, 1992; Leira, 1994). I agree. The importance of this triad will become evident later.

Despite its creation of new analytical concepts and its successful positioning on the research agenda, the tradition suffers from a theoretical flaw concerning power. I will turn to this theme. 


\section{Theorizing Care and Power}

A limited view of power is applied within feminist theories of care. Often power is limited to the kind of systemic power exercised over the carers, i.e. recognition and pay for their carework.(5) Implicit in this view is an argument about the transfer of resources and about emotional overload. This transfer introduces the question of a gender system in which women's socio-existential powers are exploited. The resources might either be labelled emotional labour, a term invented by the American sociologist Arlie R. Hochschild or love power, a concept which the Swedish-Icelandic political theorist Anna G. Jónasdóttir has coined (Hochschild, 1983; Jónasdóttir, 1991).

Despite the analytical attention to the structural location of the carer, power is hardly discussed within this tradition. A rare exception is an article by Ungerson. She mentions the possibility of elder abuse, i.e. where the carer mistreats the cared for by terrorizing her/him (Ungerson, 1997). Ungerson perceives power-over as structurally caused by the carers 'lack of power'. In her view empowerment of care users implies attention to the contexts within which carers work. In my view, power-over is not confined to such extreme situations as 'elder abuse', but is characteristic of more invisible modern forms of power which are restraining and empowering. I am referring to forms of power such as the power of discipline and bio-power, such as theorized by French historian Michel Foucault $(1977,1978)$ and postmodern feminists such as American philosopher Sandra L. Bartky. Power in their view is procedural, circulating and simultaneously restraining and producing new realities (Bartky, 1988). This view is a dynamic theorization of power which can encompass its reproduction and transformation.

Feminist research on care must theorize power as both power-to and power-over in order 
to avoid a static and one-dimensional view of power. This hardly visible, modern form of power exerts its anonymous power over the life of the individual, as seen for instance in Bentham's Panopticon (Foucault, 1977, 77). Power becomes more subtle and diffuse. Bodies and life are increasingly disciplined (Foucault, 1978, 143). More refined techniques are developed to control the self within and outside the welfare state (Donzelot, 1979).

In a Danish context, the anthropologist Anne Knudsen describes this kind of power as encroaching on the individual. An elderly man, Mr Jensen is hospitalized, and a serious, potentially lethal disease is diagnosed. In spite of everything he remains "calm, polite and almost cheerful". At their staff meetings, the nurses talk with concern about him and send for a psychologist. The absence of normal grief reactions are considered an anomaly - he is not considered good at mourning (Knudsen, 1996, 68)! Here we see the preventing and paternalistic state at work. An intervening state trying to prevent later psychical and social problems by talking about 'it', i.e. the lethal disease and his emotions. A performance of power which French historian Jacques Donzelot sees as the state's attempt to normalize and moralize over Mr Jensen (1979). Some reactions are considered more 'normal' than others.

The exercised care in the example above cannot be seen as good care, since it is exercised in accordance with what might be called a paternalistic state, and not Mr. Jensen's needs. Whereas care, generally, may be considered to create possibilities for the cared for, care is oppressing in the present example. This paternalistic state lacks a particularistic element, a respect for Mr. Jensen's individuality, since the carers unreflectively apply psychological knowledge. The disregard for Mr Jensen's individually defined need for respecting his way of mourning exposes the dark side of power.

This example illustrates the necessity of discussing how professionals exercise power (Sjørup, 1997) as well as non-professionals. In my view, this kind of professional power is like 
a two edged sword as it is both empowering and suppressive towards recipients of care. Power can create possibilities and restrain the individual. Power cannot be avoided per se in relations of care, but its effects on the recipients of care can be minimized through thinking

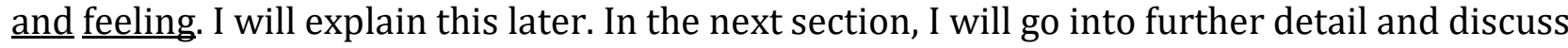
the dilemmas within care, both generally and in the welfare state; considerations intensified due to judicial administration, to justice in the state and to professionalization.

\section{Dilemmas of Care in the Welfare State}

Knudsen identifies a problem in the Danish welfare state, and possibly also in other Scandinavian welfare states. The friendly atmosphere and togetherness have another side, viz. a radical intimacy which it is difficult to refuse, whether you are patient, user or client. Knudsen suggests that caring should consist more of showing respect for the user, norms and courtesy.(6) Her argument is that care in a welfare state framework ought to be formalized to avoid encroaching on the individual - and to give people the chance to say no.

Generally, care can be characterized as a dilemma between empathy and distance. By empathy, I understand emotional responsiveness and responsibility or, as expressed by the Danish theologian Knud-Ejler Løgstrup, “... to take care of that part of another person’s life which has been handed over to you ..." $(1956,31)$. It is about a spontaneous manner - and a specific job, as pointed out by Wærness (1982). By distance and dissociation, I understand the necessity to distinguish between yourself and the other, respect for the other and an ability to understand the other's needs via this dissociation. Another form of phrasing this dilemma is as a dilemma between care for oneself and care for others, as argued by American 
psychologist Carol Gilligan (1982).

In my opinion, this dilemma is intensified in public, waged care and for several reasons. Good care requires empathy, which is more difficult when the recipient of care and the carer are strangers. At the same time, dissociation becomes more important because the carer meets the cared for as a professional and public employee and not as family member or a friend. In my view, dissociation consists of estimating a chain of events, situations and needs, partly from your professional knowledge and partly from your position as a public employee. The two roles of being a public employee and a professional create analytically distinct dilemmas between justice and love, and between knowledge and love.

Swedish social scientist Inga Michaeli argues that society in general and the welfare state are caught between two superior virtues: justice and love (Michaeli, 1995, 12, 39). Public, paid caregivers experience this dilemma as a tension between demands from the administration and from caring practices. I expect this dilemma is pushed to extremes when care takes place in private homes for longer periods, e.g. between a carer and an elderly person. Danish home helpers employed by the state have described aspects of this dilemma in interviews about their work. In analytical terms they can be seen to describe three kinds of dilemmas. One concerning the relation between intimacy versus distance, another dilemma concerning friendship versus professional secrecy, and a third dilemma concerning empathy versus rules (Kähler, 1992, 187-252). Analytically these contradictions relate to what I have redefined as three kinds of dilemmas: care of oneself contra care of the other, love contra knowledge and finally love contra justice. In the following I will concentrate upon the third dilemma, i.e. between love and justice. 


\section{Between Love and Justice}

The development of the Scandinavian welfare state(s) means that the state must protect its citizen from two kinds of threats, i.e. ensure two kinds of rights. The state must protect

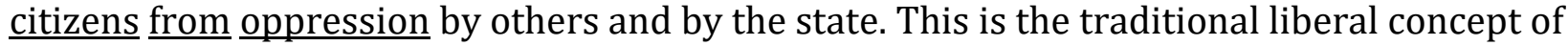
rights as ensuring freedom and equality. Simultaneously the state must also protect citizens from desertion - by others and by the state (Michaeli, 1995). On this point, Michaeli's theory criticizes traditional concepts of rights for ignoring certain dimensions of the individual's freedom such as emotional needs and procedural rights. These two aims can create dilemmas for caregivers in public, paid care. The dilemma might be illustrated with this example from Danish caring practices.

The dilemma concerns the difficult choice between justice and love in practice: the use of respite care in a nursing home.(7) The law prescribes that respite care must not be used if you are entitled to permanent placement in a nursing home. This is the perspective of justice seen as served by general rules. However, some seniors do not want to go permanently to a nursing home, but they may be willing to accept respite care in the nursing home on a temporary basis. And perhaps later they will consent to a more permanent stay in a nursing home.

The question is whether the paid, public carer shall follow the rule and get a permanent placement for the elderly person in the nursing home. Or solve the problem according to the senior's wishes, get respite care and thus ignore whether it is warranted. To follow the rule implies a correct decision in the eyes of the law, but from a caregiving point of view, it is inexcusable. The senior will either be without sufficient supervision in his/her own home or be forced into a nursing home on a permanent basis against his/her will. How can the carer make a choice in such a dilemma? The carer must choose between the correct decision in 
terms of justice or the best decision in terms of love?

However, this dilemma described by Michaeli might also be seen as a feminist metatheoretical discussion of the idea of justice. That the welfare state includes two moral visions and two conceptions of justice according to Michaeli. The requirement that the citizen must be protected against desertion signifies that public, paid care has become a public issue. This protection demands a particularism which again puts new demands on public servants. At the same time, the sympathetic insight of particularism must respect the protection of the individual, not so much in line with natural rights, cf. Hobbes, but against being emotionally overwhelmed and encroached upon.

Michaeli calls the tension between treatment based on equality and consideration for the individual's needs a collision between ethics of rights and ethics of care and responsibility. Gilligan uses the conceptions ethics of rights and ethics of care and responsibility in her research on the importance of gender for self-development and morals. In her famous book $\underline{\text { In }}$ a Different Voice, Gilligan argues that there are two moral voices connected by two different conceptions of the self and the character of responsibilities.

Ethics of rights are based on a well-defined self and moral responsibilities are characterized by principles, i.e., general rules. Ethics of care and responsibility conceive the subject as a relational self, of the individual in the community in which moral obligations are decided by the characters of the relations and of their consequences (Gilligan, 1982).

A specific moral dilemma may result in different decisions and acts as ethics of rights are based on universalism, a conception of equal rights and responsibilities for all, whereas ethics of responsibility are based on a particularism. Ethics of care and responsibility imply a specific solution in which subsummation under a general rule is impossible. Ethics of care and responsibility depend on emotional insight, i.e., putting yourself in the concrete other's place. 
Whereas ethics of rights are decided by each individual's reflection, ethics of care and responsibility are decided by empathy, a comparative estimate of the consequences different acts may have and communication with those involved(8) (Gilligan, 1982, 26-30). The dilemma might be rephrased in several ways as universalism against particularism or as two different ethical views.

Provided that caring may be identified with specific ethics, i.e., ethics of care and responsibility, based on love for the other and for the community, ethics of care and responsibility and an ethic of rights do not have to contrast each other. Neither are love and justice necessarily in conflict. They may be temporarily united in care - a theme which I will now turn to. This I will first show theoretically, then I will discuss the solution in relation to some examples.

\section{From Discourse Ethics to Interactive Universalism}

Michaeli has introduced the philosopher Seyla Benhabib and her Habermas-inspired interactive universalism to the theorization of the Scandinavian welfare state. Michaeli emphasizes Benhabib's interactive universalism as an ideal for carers in a welfare state, enabling them to make the proper ethical decisions, and at the same time respect the ethics of rights (Michaeli, 1995, 144-152). In short, an ideal which combines particularism with universalism, and which temporarily can solve the conflict mentioned by Gilligan between care for oneself and care for the other. The way I read Benhabib will be from an applicational perspective and rather less from a perspective of justice.

After a critical and feminist reading of German philosopher Jürgen Habermas' discourse 
ethics, Benhabib has developed a revised discourse ethic (Habermas, 1983; Benhabib, 1992, 109-110; 1997, 104). Benhabib aims to develop a new standard for general rules and norms which, contrary to Habermas, contextualizes the ethical decision. Like Habermas, Benhabib presupposes universal moral respect and egalitarian reciprocity, but she is even more radical than Habermas and takes for granted that everything is up for discussion. Benhabib does not accept the limit between justice and the 'good life' drawn by Habermas in a traditional liberalistic point of view, and her argument is that this limit is normative and male centered. The division between a public and a private sphere excludes, among other things, caring as a topic of public discussion (Benhabib, 1997, 102-103; 1992, 111).

Benhabib calls her ethics an 'interactive universalism', because it is not monologic like those of the German philosopher Immanuel Kant or American philosopher John Rawls, but instead dialogic. She describes her version of discourse ethics as an open collective process of moral argumentation (Benhabib, 1992, 168). The process is open, focusing on reasons for action, as in Habermas (Habermas, 1983, 59-63). The process, however, accepts and is based on a plurality of modes:

Interactive universalism acknowledges the plurality of modes of being human, and differences among humans, without endorsing all these pluralities and differences as morally and politically valid. While agreeing that normative disputes can be settled rationally and that fairness, reciprocity, and some procedure of universalizability are constituents, that is, necessary conditions of the moral standpoint...In this sense, "universalizability" is a regulative ideal that does not deny our embodied and embedded identity (Benhabib, 1992, p.153). 
Her version of discourse ethics is a regulative ideal that is both ends and means. Thus, the aim is not a consensus understood as a public opinion or a common will as Habermas described it in his earlier version of discourse ethics. Instead the aim is an agreement acceptable to all concerned, which Habermas also expressed later (Habermas, 1974, 49; 1983, 77; 1992, 3345). An agreement reached by putting yourself in the other's position thus creating greater understanding for other moral positions and needs. A process which involves a shift of perspective. German philosopher Rainer Forst describes this change of perspective as a process in which you learn something about others and yourself (Forst, 1997, 83). This position is not reached through empathy, but through an enlarged mentality an expression inspired by the German-American philosopher Hannah Arendt (Arendt, 1956, 220). According to Benhabib's Habermasian background, enlarged reasoning is reached through sensibility. Benhabib gives a description of why, in her opinion, enlarged mentality is not obtainable through empathy:

I therefore trust much less than Okin (Susan Moller Okin, HMD) (and even Gilligan) the sentiments of empathy and benevolence ... Yet precisely very empathetic individuals may also be the ones lacking an "enlarged mentality", for their empathetic nature may make it difficult for them to draw the boundaries between self and the other such that the standpoint of the "concrete other" can emerge (Benhabib, 1992, 168).

Even if Benhabib perceives empathy as emotional and related to enlarged mentality, she is extremely sceptical towards the role of emotions. She has more confidence in reflection and institutional procedures in consonance with male philosophers such as Habermas, Kant and Rawls. Feelings must in her view be controlled by sense and particular procedures. By trying 
to avoid emotions, Benhabib has probably aimed at protecting the carer from losing her autonomy. But simultaneously her suspiciousness towards feelings is also characteristic of philosophers such as Descartes and Kant. Benhabib describes the enlarged mentality like this:

It means merely making present to oneself what the perspectives of others involved are or could be (Benhabib, 1992, 137).

Consequently, it is based on a reflection of your own and the other's position. At the same time, the addition could be could also refer to a hypothetical reflection. This interpretation is confirmed, because elsewhere Benhabib also describes her interactive universalism as follows: "anticipated communication with others with whom I know I must finally come to some agreement" (Benhabib, 1992, 9). Benhabib's description is Arendt's words verbatim: it is a predicted or expected communication. Arendt describes this as the ability to put yourself in the place of all persons present - a priority of the role of fellowship as a social and normative power which Benhabib adopts (Arendt, 1956, 221).

However, Benhabib also emphasizes that taking on the other's position implies both reflection and communication: 'For me to "reverse perspectives in moral dialogue" would be more like "hearing the voice" or the story of the other' (Benhabib, 1997, 100). Apparently Benhabib emphasizes simultaneously the actual dialogue with present others and a hypothetical shift of perspective with present and not yet present others.

Benhabib contributes to the development of theories of care since her ideal can be applied to strengthen the dialogical, cognitive and hypothetical dialogic element of public carework. That is the cognitive element in one of the three elements of good care mentioned earlier: cognitive, emotional and practical - that is your head, heart and hand. Interactive 
universalism is a procedural securing of the individual seen as either as a carer or as the person cared for. $\mathrm{S} /$ he is not perceived as a general and abstract individual, but as individually given borders.

There are different elements in Benhabib's statement of the enlarged mentality. The question is whether you can apply Benhabib as a normative ideal for public caregiving? As an ideal for the good public servant exercising care? Benhabib's interactive universalism implies a shift of perspective, in which real, cognitive and potentially dialogical capabilities are exercised. However, this version of universalism contains two problems if applied as an ideal. Theoretical problems which concern a insufficient recognition of power and of the importance of emotions. These theoretical insufficiencies will be the theme of the next section, which deals with interactive universalism applied to examples of care.

\section{Interactive Universalism in Practice: Advantages and Problems}

Benhabib's interactive universalism has certain advantages. Carers applying this shift of perspective on a regular basis do not encounter problems when meeting patients or clients unable to speak and present her/his thoughts. This applies for example to people with dementia, people fully or partly paralysed after blood clots, and children before they have learned the basic structures of words and language. The carer must in such situations put her/himself in the other's position through a hypothetical reflection or leave it to others, for instance family or friends, to articulate the other's position and make her/him heard in this way.

However, her ethic also contains some problems concerning power and emotions. I will 
now analyse how interactive universalism functions in two more complex examples. The first example is Michaeli's. The example shows, from my feminist view, both an advantage and a problem with an application of an interactive universalism. The example shows how it potentially may protect the carer from unreasonable and problematic demands from the person in need of care. The threatened part is the carer. In the real life example, Lena is Per's public, waged home help. After the death of his wife, Per is lonely and depressed. Michaeli describes the developments as follows:

He falls in love with Lena and now and then she gives him a good morning or good night kiss. He starts to give her money. Lena explains that she told him that she was not allowed to receive any money from him but then Per became very distressed. She therefore accepted the money but put them in an envelope, a total sum of $2.750 \mathrm{Skr}$., determined to give them back at any time (Michaeli, 1995, 53).(9)

A public servant is not allowed to receive gifts. You could consider it attempted bribery. But from another perspective, that of reciprocity in the civil sphere, the money would be seen as a sort of gratitude for the care extended to him. The two conflicting perspectives can be seen as a conflict between justice and love, or alternatively between the application of general principles (justice) and care. According to Michaeli, interactive discourse ethics would give Lena a better position to handle stubborn people (Michaeli, 1995, 55). In short, the demand would be a conversation enabling you to discuss the motive and the meaning of the present. Lena could here reflect on how Per perceives the situation - as an expression of gratitude, convention or the idea that you can buy love, or is he just becoming senile? In a dialogue she could try to reach an agreement with him by placing herself in his place. 
If they are unable to agree according to Benhabib you can either leave the question to individual choice or treat it strategically when the two sides agree to disagree (Benhabib, $1997,101,109)$. The issue cannot be left to an individual choice as Benhabib argues as a solution, since it takes place in public, waged care. Another option for Lena is to contact her superior and present the matter to her/him. However, in a moral conversation, she is forced to motivate her act(s) in relation to various moral standards. This will make the dilemma, its interpretations and considerations more visible. Interactive universalism may protect the carer against insatiable and unreasonable (emotional) demands, although it does not change the structural relations that have to do with power and gender. Carers, most often women, are explicitly forced to reflect on and share their reflections with others in the interactive universalism. This requires time in order to occur. But when it occurs, it can function as a protection of the carer, i.e. Lena.(10)

At the same time, Benhabib would argue that the position spoken from is made visible - its special position. That power can be exposed, but that it does not necessarily happen. The dialogue, however, has room for resistance against power as the arguments' value can be examined. However, there are limits to a power free discourse as the example with Lena shows. Her 'no' does not have the same weight as a male 'no' as argued by British political theorist Carole Pateman (Pateman, 1988). However, Benhabib seems overly confident that cognitive powers can expose power, which seems rather naive given the new, subtle forms of power mentioned earlier, disciplining power and bio-power, which Foucault has described in more general terms.

The shift of perspective to the concrete other makes interactive universalism superior to Habermasian discourse ethics in terms of how the carer actually puts her/himself in the other's place and considers how the other would interpret her/his arguments, e.g., a rejection 
of a gift. It implies a potential protection of the carer, as s/he is forced to put into words her experience of the situation and thereby to 'see' her position from the outside.

Whereas interactive universalism may protect people against being emotionally overwhelmed and exploited, the change of perspective does not protect the receiver of care from insensitivity. Benhabib has excluded this part of particularism.(11) The exclusion of an emotional basis creates a problem for the cared for. Its insufficiency can be illustrated by the following example. Edith, an elderly woman living by herself, has just had a stroke at home and has been hospitalized. After a few days her condition is satisfactory and the hospital wants to send her home.

Originally, Edith was alone for quite some time after her stroke before someone from her network discovered that something was wrong. Consequently, she is afraid to be sent home alone in case the situation might repeat itself. In this situation, interactive universalism is insufficient. Interactive universalism implies that you put yourself in the other's place and start a dialogue with the elderly woman and relatives - that various alternatives are discussed such as a personal security alarm, nursing home and visits several times a day, or a sort of hearing with relatives if Edith herself is unable to speak. But this is not enough. A perception of her fear is a necessary condition which must be observed so that the usual practise for discharging patients is not followed automatically in the actual case. Consequently, Benhabib's interactive universalism is insufficient. Her dialogical universalism must be combined with an element of empathy in order to function properly, which I will return to.

Interactive universalism implies a potential protection of the carer and the recipient, but it also contains two weak points. For instance, Benhabib throws suspicion on the emotional and insufficiently theorizes power. My ideal of a good public servant requires that the role of feelings be integrated if emotional indifference is to be avoided. My ideal also requires that 
power is understood better if a paternalistic state is to be avoided. I will now turn to a more adequate theorization of emotions which I believe will balance thinking and feeling. A better balance might minimize some of the effects of power.

\section{Emotions and Compassionate Authority}

Benhabib articulates the cognitive element in which you think as if you were in the other's place or participate in an actual, moral dialogue. Benhabib, however, seems to reject any role of emotions on the basis of her Enlightenment heritage. This leads her to identify emotions with total identification, i.e. a loss of autonomy. In contrast, I will argue theoretically that her interactive universalism requires an emotional element in order to function properly, and that this element can be found in the notion of empathy Vetlesen argues in favor of and in Jones' notion of compassionate authority.

Benhabib lacks an understanding of the positive role some emotions can have in ethics, and thus also as a basis for the interactive universalism. Interactive universalism can be thought of as a protection of the carer against being emotionally overwhelmed and exploited, but what about lack of care as the ultimate consequence of emotional indifference? How can we theorize emotions?

As pointed out by Arne Johan Vetlesen, it does not necessarily have to be an either-or choice when it comes to the role of reflection and feelings in morals and ethics (Vetlesen, 1994). On the contrary. The role of emotions does not have to be ideosyncratic and dangerous. His project is generally to combine respect and concern --- a cognitive element with an emotional one (Vetlesen, 1994, 13).(12) Concern is understood here as a basic human 
ability. This concern for the other is defined as empathy: as an attention towards the other which is not a feeling but a general being-in-the-world-with-others. It is not hereditary, but demands cultivation. Without empathy you will never be aware of the other's needs, e.g., as a need for care or in order to identify a situation as ethical. Empathy is an ability for understanding (Vetlesen, 1994, 326) assuming that the persons involved know each other or that they are face-to face. Vetlesen does not regard empathy as being identical with a total identification and perception of the other's state of mind. Empathy requires a relation and an attention towards the other.

It is by virtue of this faculty that I can put myself in the place of the other by way of a feeling-into and feeling-with ... empathy facilitates the first reaching out toward and gaining access to the other's experience ... it does not mean that I myself come to feel what the other feels. I do not have to feel the others' sentiments in order to grasp, and thereupon to be able to judge in light of, how the other experiences the situation he or she is in. The feeling-with made possible by the faculty of empathy is no mere projection (Vetlesen, 1994, 8).

Vetlesen here describes empathy as the basis for the human social and political sense of community indicating an attentiveness and concern towards the other(s).

In order to function properly interactive universalism requires a feeling-with the other, and that you pick up a need for care, e.g. the interactive universalism's change of perspective. Benhabib's fear of the unknown, that which threatens the male order also perceived as the feminine, which she seems to identify with an emotional engulfment, leads her to a universalist bias. This bias implies that her proposal for reaching moral agreement, interactive universalism without emotions, becomes inadequate as a practical tool. Emotions 
might also have helped Mr. Jensen. A more perceptive carer might have exercised more individualized care, understood his needs for being alone and acted accordingly.

A role assigned to emotions in the state can be found in the theorizing of the political theorist Cathleen B. Jones (1993), who argues in favour of a concept of compassionate authority.(13) Jones' argument is that the idea of authority up till now excludes women and femininity as symbols because the male view of authority understands it as indivisible, unambiguous and hierarchical. The classic example is Hobbes, who understood authority as sovereignty, i.e., the power of the sovereign. Instead, Jones suggests a compassionate authority which, via an emotional relation, commits us to a specific context. This is an authority which is more horizontal than in than the classical hierarchical relation in the German sociologist Max Weber's notion of rational authority.(14) Jones rethinking of authority thus contains elements of equality, heterogeneity and inequality. Authority in her view is also about speech, communication and a common understanding (Jones, 1993, 21-22) which fits perfectly with a revised interactive universalism. Especially the differences between those exposed to authority can be taken into account, which in Benhabib's words would mean a recognition of a 'plurality of modes'.

In this ideal, I modify Benhabib’s interactive universalism by combining it with Vetlesen's understanding of empathy and Jones' reconstruction of authority as compassionate. Only through theorizing emotional elements can they be understood as part of good care thereby contributing to the avoidance of emotional indifference. I turn now to another of the three dilemmas, that between love and knowledge. 


\section{Between Love and Knowledge: Professional Care}

This dilemma in public, waged care be seen as an either-or choice between the most professional treatment or the most kind. Where professional care is often perceived as based on scientific knowledge and a pervasive division of labour. Love and knowledge, however, are not necessarily opposites, they can be related. This I will do when explaining an alternative professional ideal which again presupposes an ideal for good care. I perceive good care as possessing an emotional commitment on behalf of the carer without signs of emotional exploitation as in Lena's case. Good care should also imply interactive universalism, both as putting yourself hypothetically in the other's place and as an actual dialogue if possible. Good care unites the cognitive, emotional and practical aspects or, as described by American resident writer Agnes Heller, 'Fühlen heißt in etwas involviert zu sein. Dies Involviertsein ist, ..., inhärenter bestandteil von Handlung und Denken, nicht aber deren Begleitserscheinung' (Heller, 1981, 25). Emotions are not separate, but part of thinking and doing.(15)

Which professional ideal secures good care as in a perceptive and reflective state, and as described above? Martinsen outlines an ideal type of professionalism, where spontaneity is emphasized and understood as an emotional spontaneity concerning trust and compassion. Martinsen understands knowledge as an experience based knowledge understood as phronêsis-knowledge. Already Aristotle described this particular form of knowledge in his Ethics $(1987,209-210)$. Aristotle understood phronêsis as based upon experience where morally good attitudes were achieved as well. A kind of ethical know how (Martinsen, 1994, 97). As expressed by Martinsen it is a knowledge '... which I acquire when I emotionally put myself in the situation' (Martinsen, 1994, 99). She considers this emotionally acquired knowledge tied to personality and body. 
This phronêsis knowledge is connected with the proper perception --- the historically and conventionally given perception of good care which also takes the actual other into consideration. Thus, morality becomes situational ethics. Feelings here have a positive function as a basis for knowledge and as related to ethics understood as the right thing to do. Emotions become oriented towards action and are physically included in the understanding of the good professional. Martinsen understands emotions as being tied to the body as physical, cultural expressions. At the same time, however, Martinsen's professional ideal is too radical. It goes too far in its priority of the emotional commitment.

The good professional is aware of the other and the other's situation without projection or total identification. This empathy must secure that interactive universalism does not result in disengagement from emotions and thus in insensitivity. Martinsen contributes to my ideal with a wider perception of knowledge, but she ignores 'emotional labour' (Hochschild, 1983). A kind of work which puts spontaneity in brackets in order to create a specific and apparently spontaneous atmosphere around a patient, user or client if, for example, the cared for needs encouragement. Hochschild's concept of 'emotional labour' is important to keep in mind, since it implies that emotions to a certain extent can be controlled, in contrast to Martinsen's celebration of spontaneity.

In this section, I have argued in favour of a new professional ideal inspired by Martinsen. It requires a different understanding of being a professional and also of the carer's education, employment conditions and the organization of care.(16) Respect is embedded in a procedural guarantee where the carer puts his/herself in the other's place and simultaneously seeks to maintain an empathic element. 


\section{Conclusion}

'The Private is political' - one of the slogans from the new Women's Movement. Paradoxically this has become a reality today for a major part of state provided care. Formerly 'private' tasks have entered the welfare state and care has become a political allocation issue. At the same time those cared for are increasingly exposed to the power of discipline and bio-power which has a moralizing and normalizing effect, as in the example with Mr Jensen. Power and its negative effects on the cared for might be diminished by this new, normative professional ideal for care in the welfare state, but of course never avoided altogether.

In this article I have argued that three analytically distinct dilemmas exist in carework taking place within the state. These dilemmas have generally not been sufficiently discussed, especially in relation to which normative ideal should apply to the professional public official exercising care. I will suggest a normative ideal: a perceptive and reflective state which places itself between the ideals of the perceptive and the non-paternalistic state. I suggest a revised version of interactive universalism in which empathy plays a role, i.e., a combination of cognitive, dialogical and emotional elements. In which the procedural principle demands that the other's position and needs are taken seriously, even if the other is unable to express her/himself in words. Towards the end of this article, I have revisied and narrowed down the understanding of empathy as an attention towards the other, which is not a total identification with or projection on the other such as Benhabib seems to understand it. Empathy is not in itself a feeling, but a precondition for emotions in general. I suggest a professional ideal for carework in which the emotional side is experienced as an integrated part of a unity. An ideal combined with Jones' idea of compassionate authority and in which bodily expression is recognized as a part of the emotional labour within caring. 
My modified form of interactive universalism with its element of empathy ensures that the perceptive and reflective state will neither result in a paternalistic state nor in a rule following, bureaucratic state without empathy. My normative ideal has two important implications. First there is a general element which protects the recipient of care regardless of gender against both emotional engulfment and indifference. Secondly, there is also a feminist aim which might protect the carer against emotional overload and unsolvable cross-pressures through the change in perspective. This normative ideal has implications for the way carework and caring practices within the welfare state should be organized. Accepting my position would require more time for good care to be exercised, and a more public space for the discussion of the standards for care, taking into account the dilemmas between care of the other and care of oneself, justice versus love and knowledge versus love. Sadly, the Scandinavian welfare states seem to be developing in a way which moves away from this ideal through its present policies of marketization and rationalization.

I would like to thank the following for constructive contributions to the content and presentation of the earlier drafts of this article: Gitte Høstgaard Andersen, Niels Åkerstrøm Andersen, Pia Vedel Ankersen, Anette Borchorst, Hanne Nexø Jensen, Kristian Kindtler, Henrik Kaare Nielsen, Per Mouritsen, Jørgen Poulsen, Birte Siim and the anonymous reviewers of The European Journal of Women's Studies.

\section{Notes}

(1) The term 'state' is applied as an abstract concept, which does not presuppose a unitary 
agent. The 'state' is represented at various levels by agents in various caring practices.

(2) I use 'empathy' in a broad sense, roughly synonymous with 'sympathy'. Later in this article I will define it in a narrower way inspired by Norwegian philosopher Arne Johan Vetlesen.

(3) My focus implies that I disregard the present development of marketization/privatization of care, since I have discussed this elsewhere (Dahl and Michaeli, forthcoming). Normally I would distinguish between 'carework' and 'professional care' like the British nurse Celia Davies in order to differentiate analytically between paid care with no professional status and paid, professional care (1995). However, in the remainder of the article I will refer to waged, public care regardless of its professional or non-professional status.

(4) This argument applies to care except acute care taking place in casualty wards, where urgent responses are necessary. By acute care I mean highly technical care in those parts of a hospital which deal with patients who have been involved in accidents, e.g. life and death situations.

(5) An exception would be British sociologists Jenny Hockey and Allison James, who have investigated the discourses on elderly in Britain, especially their marginalization and humiliation (Hockey and James, 1993)

(6) She argues an anti-feminist position, since she describes 'good service' as 'invisible' (1996, 72). This ideal is anti-feminist since feminism has attempted to describe, re-evaluate and make 'visible' care.

(7) The example is from a term paper by students Ditte Bjerregaard Jensen and Eva Pallesen in the spring of 1997 entitled: 'Dilemmas within public care--professional caregivers' selfknowledge in a theoretical light', Department of Political Science, University of Aarhus, unpublished.

(8) Ethics of rights contain elements of an already known ethic position as, e.g., German 
philosopher Immanuel Kant's categorical imperative. Ethics of care and responsibility have elements of Aristotle's consistency ethics and of Løgstrup's ethics of situation, and at the same time it contains a universalism in its particularism: everyone has the right to be treated as a concrete other.

(9) The sequence is my translation from Swedish.

(10) My assumption is that only the carer changes perspective in case the person cared for, for various reasons, is unable to do so.

(11) Benhabib's ideal does not include these emotional aspects, although she is critical of what she calls "cognitive rationalism", rationalism ignoring the individual's foundation in human relations and the emotional basis of morals of which she considers Kant an exponent (Benhabib, 1990, 355-359).

(12) Here I narrow down my use of the concept 'empathy' to Vetlesen's. 'Sympathy' and 'empathy' are consequently no longer synonymous terms. See note 1.

(13) Jones suggests the concept of "maternal authority" which is problematic from a feminist point of view. It gives a feeling of exclusion. Everyone is born, but not everyone is a mother (Moruzzi, 1996, 553).

(14) The German sociologist Max Weber summarized our norms for a legal administration and the good public servant in the beginning of this century. Weber's theories are the ones most applied to the conduct of civil servants today. He describes administrative decisions as characterized by two outstanding virtues, predictability and impersonality (Weber, 1956). Impersonality is described as follows: "sine ira et studio', ohne Haß und Leidenschaft, daher ohne 'Liebe' und Enthusiasmus" $(1956,129)$. The neutrality demand was important in relation to the forms of administration Weber confronted, which were characterized by nepotism and arbitrariness. His idea of rational authority is about a hierarchical power of 
command. Relations to others become technical-instrumental and the individual is interchangeable. The norms for the good public servant erase feelings; knowledge is seen as generalizable, and specific incidents only as subsumption under a general rule or employment of general knowledge.

(15) Emotions, however, can be positive or negative such as argued in a classic text by British sociologist Clare Ungerson. Examples of the negative type are feelings of shame, fear and hate (Ungerson, 1983).

(16) As an example, Swedish researcher Stina Johansson argues in favor of an alternative professional ideal implying full-time employment and a possibility for a lifelong career through which you can improve the qualifications for development possibilities in care conditions that give the employees peace and security to develop their practical, emotional and cognitive qualifications (Johansson, 1995).

\section{Bibliography}

Arendt, Hannah (1956) Between Past and Future. London: Penguin.

Aristotle (1987) Ethics. London: Penguin.

Bartky, Sandra L (1988) 'Foucault, Femininity, and the Modernization of Patriarchal Power', in

I. Diamond \& L. Quinby (eds) Feminism \& Foucault--Reflections on Resistance. Boston: Northeastern University Press.

Benhabib, Seyla (1990) 'Afterword', pp. 330-371 in Seyla Benhabib et al. (eds) The Communicative Ethics Controversy. Cambridge: MIT Press.

Benhabib, Seyla (1992) Situating the Self. Cambridge: Polity, Cambridge. 
Benhabib, Seyla (1997) 'On reconciliation and respect, justice and the good life', Philosophy and Social Criticism 23(5): 97-114.

Bubeck, Diemut (1995) Care, Gender and Justice. Oxford: Clarendon Press.

Dahl, Hanne Marlene (1997) 'Mellem kærlighed og arbejde' (Between Love and Work), Kvinder, Køn og Forskning 6(2): 56-65.

Dahl, Hanne Marlene and Inga Michaeli (Forthcoming) Restructuring of Care? Or New Forms of an old Dilemma?

Davies, Celia (1995) ‘Competence versus Care?' Acta Sociologica. 38: 17-31.

Donzelot, Jacques (1979) The Policing of Families. New York: Pantheon.

Eliasson, Rosmari (1992) 'Omsorg och rationalitet', in R. Eliasson Egenheter och Allmänheter. Lund: Arkiv Forlag.

Finch, Janet (1989) Family Obligations and Social Change. Cambridge: Polity.

Forst, Rainer (1997) 'Situations of the self', Philosophy and Social Criticism, 23(5): 79-96.

Foucault, Michel (1977) Discipline and Punish. London: Penguin.

Foucault, Michel (1978) The History of Sexuality. Suffolk: Penguin.

Gilligan, Carol (1982) In a Different Voice. London: Harvard University Press.

Graham, Hilary (1983) 'Caring: A Labour of Love', in Janet Finch and Dulcie Groves (eds) $A$ labour of Love--Women, Work and Caring. London: RKP.

Graham, Hilary (1991) 'The concept of Caring in Feminist Research', Sociology, 25(1): 61-78.

Graham, Hilary (1993) 'Social Divisions in Caring', Women's Studies International Forum 16(5): 461-470.

Habermas, Jürgen (1974) 'The Public Sphere’, New German Critique 6(3): 49-55.

Habermas, Jürgen (1983) Moralbewußtsein und Kommunikatives Handeln. Frankfurt: Suhrkamp. 
Habermas, Jürgen.1992) Faktizität und Geltung. Frankfurt: Suhrkamp.

Heller, Agnes (1981) Theorie der Gefühle. Hamburg: VSA-Verlag.

Hochschild, Arlie (1983) The Managed Heart. Berkeley: University of California Press.

Hockey, Jenny and Allison James (1993) Growing Up and Growing Old. London: Sage.

Johansson, Stina (1995) 'Introduktion', Stina Johansson et al. (eds) Sjukhus og hem som arbetsplats. Stockholm: Bonnier Utbildning.

Jónasdóttir, Anna G. (1991) Love Power and Political Interests, Kumla: Örebro Studies.

Jones, Kathleen B (1993) Compassionate Authority. New York: Routledge.

Kähler, Margrethe (1992) Faste Forhold ønskes. København: Sikon.

Knudsen, Anne (1996) Her går det godt - send flere penge. København: Gyldendal.

Leira, Arnlaug (1994) 'Concepts of caring', Social Service Review 68(2): 185-201.

Løstrup, Knud-Ejler (1956) Den etiske fordring. København: Gyldendal.

Martinsen, Kari (1994) Fra Marx til Løgstrup. København: Munksgaard.

Michaeli, Inga (1995) Omsorg och rättvisa - ett dilemma. Gävle: Meyers.

Moruzzi, Norma C (1996) 'Review-Article’, Political Theory 24(3): 549-556.

Pateman, Carole (1988) The Sexual Contact. Cambridge: Polity.

Sjørup, Karen (1997) 'Velfærdsstaten som middel i kvinders magtspil' (The Welfare State as a Tool for Women's Power Games), Kvinder, Køn og Forskning 2: 6-15.

Thomas, Carol (1993) 'De-constructing Concepts of Care', Sociology 27(4): 649-669.

Ungerson, Clare (1983) 'Women and Caring: Skills, Tasks and Taboos', in E. Garmanikow et al. (eds) The Public and the Private. London: Heinemann.

Ungerson, Clare (1987) Policy is Personal. London: Tavistock.

Ungerson, Clare (1995) 'Give them the Money: Is Cash a route to Empowerment?' Social Policy and Administration 31(1): 45-53. 
Ungerson, Clare (1997) 'The commodification of Care: Current Policies and Future Politics', in Barbara Hobson og Anne Marie Berggren Crossing Borders. Stockholm: Forskningsrådsnämnden.

Vetlesen, Arne Johan (1994) Perception, Empathy, and Judgement. Pennsylvania: The University Press.

Weber, Max (1956) Wirtschaft und Gesellschaft. Tübingen: J.C.B. Mohr.

Wærness, Kari (1982) Kvinneperspektiver på socialpolitikken (Women’s Perspectives on Social Policy). Oslo: Universitetsforlaget.

Wærness, Kari (1987) 'On the rationality of caring', in Anne Showstack-Sassoon (ed.) Women and the State. London: Hutchinson. 